\title{
ДО ПИТАННЯ ПРО СПІВРОБІТНИЦТВО ПОЛІЦІЇ ТА ГРОМАДЯН У СФЕРІ ЗАХИСТУ Й ОХОРОНИ ГРОМАДСЬКОГО ПОРЯДКУ
}

Калаянов Д. П.

У статті йдеться про те, що діяльність поліціі здійснюється в тісній співпраці та взаємодії з населенням, територіальними громадами та громадськими об'єднаннями на засадах партнерства і спрямована на задоволення їхніх потреб. Визначаються чинники, що призводять до невдач у спробах упровадження програм профілактики поліції в місцевих органах влади. Констатується, що поліція ще не контролюється суспільством належною мірою, і поліція не орієнтується на громадськість, їі можливості та потреби, тому й не можна визнати таку діяльність ефективною. Аналізується вітчизняна правова система, що містить низку юридичних норм, які дозволяють громадянам активне включення в діяльність із гарантування безпеки. Розглядаються форми співпраці між поліцією і громадянами, які застосовуються в передових країнах для підвищення рівня безпеки місцевих громад. Наводяться приклади того, як обидві сторони доходять порозуміння, що партнерство є найкращим способом побудови безпеки. Зокрема, аналізується загальнодержавна програма «Національна карта загроз безпеці», яка використовується в Польщі. Завдяки такій програмі громадянин може через інтернет відзначити місце, у якому виникають небезпечні ситуації. Підкреслюється, що працівники поліції превентивної діяльності не можуть бути анонімними для мешканців району, який вони обслуговують. Вони повинні бути знайомими і викликати довіру. Контакти працівників такої служби з мешканцями мають бути побудовані за допомогою заходів, які не пов'язані зі слідчою або оперативно-розшуковою роботою. Визначаються можливості для використання таких форм співробітництва в українському суспільстві. Також для виправлення ситуації необхідно ухвалити програмний документ про взаємодію поліції і громадянського суспільства, ширше залучати громадян у роботу поліціі, проводити відповідну інформаційну кампанію, готувати поліцейських до взаємодії з населенням. Партнерство в галузі гарантування громадської безпеки та громадського порядку дозволить виявляти, ідентифікувати та ліквідувати криміногенні чинники, перш ніж вони загострюються. Таке співробітництво підвищує в місцевих громадах переконання про його реальний вплив на безпеку в місці проживання.
Ключові слова: поліція, взаємодія, загрози безпеці, громадський порядок.

Kalaianov D. P. Police and citizen cooperation in the protection and defense of public order

The article says that police activities are carried out in close cooperation and interaction with the population, territorial communities and public associations. At the same time, the principles of partnership are used, which are aimed at meeting their needs. The factors that lead to failures in attempts to introduce police prevention programs in local authorities are determined. It is stated that the police are not yet properly controlled by the society, and the police are not guided by the public, its capabilities and needs, therefore, such activities cannot be recognized as effective. The Ukrainian legal system contains a number of legal norms that allow citizens to be actively involved in security activities. The article discusses the forms of cooperation between the police and citizens, which are used in advanced countries to improve the security of local communities. Provides examples of partnerships that are the best way to build security. In particular, the national program "National Security Threats Map", which is used in Poland, is analyzed. Thanks to such a program, a citizen can mark the place where dangerous situations arise via the Internet. It is emphasized that police officers cannot be anonymous to residents of the area they serve. They should be familiar and trustworthy. Contacts of employees of such a service with residents should be built using measures not related to investigative or operationalsearch work. The possibilities for using such forms of cooperation in the Ukrainian society are determined. Also, to correct the situation, it is necessary to adopt a program document on the interaction of the police and civil society, to more widely involve citizens in the work of the police, to conduct an appropriate information campaign, and to prepare police officers for interaction with the population. Partnership in the field of public safety and public order will identify, identify and eliminate criminogenic factors before they escalate. Such cooperation raises the belief in local communities that it has a real impact on safety at home.

Key words: police, interaction, security threats, public order.

(с) Калаянов Д. П., 2020 
До найважливішої сфери управління кожної держави включають турботу про безпеку громадян та забезпечення громадського порядку. Державна адміністрація повинна вживати заходів, спрямованих на підвищення почуття безпеки громадян, а також усунення загроз, які суттєво впливають на якість їхнього життя. Вирішення проблем, які турбують місцеву спільноту, а отже, впливають на почуття безпеки, - це не просте завдання. Передусім необхідно визначити, які соціальні проблеми сприймаються місцевою громадою як такі, що створюють загрозу, а потім шукати шляхи їх вирішення. Підтримання на належному рівні громадської безпеки та порядку $\epsilon$ основною умовою стабільного функціонування держави.

Відповідно до Указу Президента України «Про рішення Ради національної безпеки і оборони України від 4 березня 2016 р. «Про Концепцію розвитку сектора безпеки і оборони України»» від 14 березня 2016 р. № 92/2016, підтримання публічної безпеки і порядку Міністерством внутрішніх справ України та Національною поліцією України визнано одним з основних напрямів розвитку складових частин сектора безпеки і порядку в державі [1] (одразу варто зауважити, що на сучасному етапі розвитку законодавства терміни «публічна безпека» $\mathbf{i}$ «публічний порядок» ми вважаємо рівнозначними $з$ поняттями «громадська безпека» та «громадський порядок»).

Питанням гарантування та підтримання публічної безпеки й порядку присвятили свої праці О.М. Бандурка, І.П. Веремеєнко, І.П. Голосніченко, Є.В. Додін, В.К. Колпаков, А.Т. Комзюк, О.І. Остапенко й інші.

Ухвалення 2 липня 2015 р. Верховною Радою України Закону «Про Національну поліцію» зумовило запровадження оновленої концепції функціонування Національної поліції, регулювання правових засад організації та діяльності цього органу. Зокрема, у ст. 11 «Взаємодія з населенням на засадах партнерства» проголошується, що «діяльність поліції здійснюється в тісній співпраці та взаємодії з населенням, територіальними громадами та громадськими об'єднаннями на засадах партнерства і спрямована на задоволення їхніх потреб».

Принцип взаємодії з населенням на засадах партнерства визначає, що діяльність поліції здійснюється в тісній співпраці та взаємодії з населенням, територіальними громадами та громадськими об'єднаннями на засадах співробітництва і взаємної відповідальності та спрямована на задоволення їхніх потреб. Законодавець на концептуальному рівні закріпив партнерську модель відно- син української поліції і суспільства, орієнтовану на співробітництво поліції з інститутами громадянського суспільства та громадянами у процесі протидії злочинності, охорони та гарантування публічної безпеки та порядку.

В основі партнерської моделі відносин поліції і населення лежить низка важливих компонентів. Вона передбачає, зокрема, що поліція не стоїть над суспільством, а служить йому, орієнтується на співпрацю з інститутами громадянського суспільства та громадянами у процесі захисту їхніх прав і свобод, протидії злочинності, охорони громадського порядку, прагне забезпечувати суспільну довіру до себе і підтримку громадян. Ця модель передбачає ввічливе й уважне ставлення поліції до громадян, бездоганний зовнішній вигляд поліцейського, розумну відкритість поліції для громадського контролю, залучення громадян до запобігання протиправним діям, бездоглядності дітей, підлітків, наркотизації й алкоголізації населення тощо. Дії працівників поліції повинні бути обґрунтованими і зрозумілими для громадян. Тому для визначення причин і умов учинення правопорушень службова діяльність органів поліції здійснюється з урахуванням специфіки регіону та проблем територіальних громад. Отже, рівень довіри населення до поліції $\epsilon$ основним критерієм оцінки ефективності діяльності органів i підрозділів поліції. Оцінка рівня довіри населення до поліції також проводиться незалежними соціологічними службами, відповідно до Порядку проведення оцінки рівня довіри населення до Національної поліції, затвердженого постановою Кабінету Міністрів України від 7 лютого 2018 р. № 58.

Водночас варто констатувати, що раніше наявний позитивний досвід взаємодії органів внутрішніх справ і громадянського суспільства багато в чому втрачений. Проведена реформа поліції, покликана залучити інститути громадянського суспільства до контролю над поліцією, поки далека від завершення [2]. На жаль, поліція ще не контролюється суспільством належною мірою, а поліція не орієнтується на громадськість, її можливості та потреби, тому й не можна визнати діяльність із забезпечення контролю над злочинністю ефективною, оскільки громадяни не мають почуття впевненості в безпечному середовищі, а брак живого спілкування між ними спричиняє подальше дистанціювання між поліцією і громадськістю. На нашу думку, для виправлення ситуації необхідно ухвалити програмний документ про взаємодію поліції і громадянського суспільства, ширше залучати громадян у роботу поліції, прово- 
дити відповідну інформаційну кампанію, готувати поліцейських до взаємодії з населенням.

Таку роботу вже розпочато. В Україні $\epsilon$ багато програм, спрямованих на спільну діяльність у сфері підвищення безпеки та громадського порядку. Наприклад, програма «ПОЛіС» («Поліція і суспільство») $є$ частиною проєкту «Залучення громадськості до реформ». Він утілюється Радою міжнародних наукових досліджень та обмінів (IREX) у партнерстві з Міністерством внутрішніх справ України, Міжнародною організацією з розвитку права (IDLO) та за фінансової підтримки Відділу із правоохоронних питань (INL) посольства США. Програма покликана побудувати плідну співпрацю між поліцією та тими, для кого вона працює і кого захищає, зокрема, за допомогою зустрічей представників місцевої поліції та громадськості в бібліотеках, на інших публічних платформах. Головним завданням проєкту «Шкільний офіцер поліції» $\epsilon$ створення безпечного середовища в закладах загальної освіти. Воно реалізується через здійснення ефективної профілактики правопорушень серед учнів, застосування відновних практик для запобігання конфліктам, правопорушенням та іншим негативним явищам. Проєкт «Шкільний офіцер поліції» $є$ моделлю співробітництва закладів загальної освіти й управлінь патрульної поліції Департаменту патрульної поліції в Києві, Одесі, Івано-Франківську та Львові. «Сусідська варта» це проєкт, який реалізується для підвищення відповідальності власників будинку за свою безпеку. Співпраця з поліцією в такому напрямі $\epsilon$ основоположною. Патрульні разом із дільничними офіцерами зустрічаються з мешканцями, спілкуються про проблеми району.

Такі програми мають стимулювати ініціативу й активізувати діяльність місцевих громад. В Україні все одно поширене переконання, що саме на правоохоронних та інших адміністративних органах лежить обов'язок ініціювати таку діяльність. На нашу думку, важливо, щоб рішення про вжиття профілактичних та запобіжних заходів народжувалося серед представників місцевих громад. Часто спроби впровадження програм профілактики поліції в місцевих органах влади території закінчуються невдачею через відсутність порозуміння з місцевим самоврядуванням. Причиною цього можна вважати такі чинники. як: пасивне ставлення органів самоврядування; ігнорування цієї проблематики в органах місцевої влади; небажання громади; переконання, що профілактика правопорушень - це суто поліцейська проблема; недостатня співпраця на рівні «поліція - місцеве самоврядування».
Зараз жодна інституція, яка відповідає за безпеку, не спроможна правильно функціонувати без соціальної підтримки, а найкращі результати у профілактиці і боротьбі зі злочинністю приносить взаємодія громадськості з поліцією. Суспільство і поліція повинні спільно вирішувати питання, що є суттєво важливими з погляду протидії загрозам безпеці. Однак варто підкреслити, що поява дільничного офіцера поліції в помешканні, житлі або на сходовому майданчику, його спроби встановити контакт із мешканцями (щоправда, дедалі рідше) $є$ чимось незвичайним.

Ось чому дуже важливо боротися зі стереотипним переконанням у тому, що фінансування поліції платниками податків рівносильне зобов'язанням гарантувати належний рівень безпеки без необхідності будь-якої участі в цій справі з боку самого суспільства.

Вітчизняна правова система містить низку юридичних норм, що дозволяють громадянам активне включення в діяльність із гарантування безпеки. Найважливішими є: необхідна оборона, стан крайньої необхідності, так зване «громадське затримання» у порядку ст. 207 Кримінального процесуального кодексу України (тобто затримання не уповноваженою службовою особою (поліцейським), а просто цивільною особою, до прибуття поліції), надання допомоги поліцейському, обов'язок повідомляти правоохоронні органи про вчинення правопорушення, обов'язок співпраці поліції із громадськими організаціями, обов'язок співпраці між органами місцевого самоврядування та неурядовими організаціями.

Отже, імовірно, варто поставити запитання: чи ми вже побудували громадянське суспільство? Чи, можливо, має рацію відомий британський соціолог та філософ Р. Дарендорф, який стверджує, що демократія може бути встановлена через півроку після проведення демократичних виборів, побудова ринкової економіки можлива через шість років після запровадження економічних реформ, лише через шістдесят років формується громадянське суспільство?

Тому варто розглянути, яка форма співпраці між поліцією і громадянами, метою якої $\epsilon$ підвищення рівня безпеки місцевих громад, може бути використана українським суспільством.

Про необхідність створення карт 3 інформацією про злочинність сказав В. Браттон, який 2 грудня 1993 р. був представлений мером НьюЙорка Р. Джуліані як новий очільник місцевої поліції. У кожному районі було створено карту із кримінальними даними, на основі якої надалі пла- 
нувалася дислокація служб. Керівник поліції НьюЙорка вирішив довести, що теорія про злочини як результат специфічної соціальної ситуації, на яку поліція не може впливати, не відповідає дійсності. Він уважав, що поліція може справляти значно більший вплив на створення й поширення причин та умов правопорушень. Водночас він зазначив, що створення відповідних поліцейських структур дозволить ефективно боротися зі злочинністю та підвищити рівень почуття безпеки жителів.

Такий корисний досвід руху поліції назустріч громадськості можемо спостерігати в найближчих європейських сусідів.

Для підвищення ефективності діяльності поліції та з метою посилення співпраці із громадськістю в Польщі 13 червня 2016 р. було представлено загальнодержавну програму «Національна карта загроз безпеці» [3]. Карта загроз базується на каталозі інформації у трьох вимірах.

1. Інформація, зібрана в інформаційних системах поліції.

2. Інформація, отримана від громадськості під час:

- прямих контактів із громадянами, представниками місцевого самоврядування та неурядових організацій тощо;

- суспільних дебатів із питань громадської безпеки.

3. Інформація, отримана від громадян - користувачів інтернету за допомогою платформи обміну інформацією.

Тепер кожен громадянин може через інтернет відзначити місце, у якому, на його думку, виникають небезпечні ситуації. Ця карта $\epsilon$ свого роду інтернет-консультацією із суспільством. Поліція перевіряє кожне повідомлення i peaгує відповідним чином. Сервіс пропонує також і можливість повідомити про загрозу анонімно. Водночас цей сервіс - аж ніяк не заміна номерам екстрених служб.

Внесення загрози застосовується шляхом вказування на інтерактивну карту однієї із 25 категорій загроз, представлених там. Це загрози, які мають вирішальний вплив на рівень почуття безпеки. До них належать: акти вандалізму; безпритульність; необладнані купальні зони; стихійні сміттєві звалища; браконьєрство; місця групування неповнолітніх; небезпечні місця в акваторіях; незаконні рубки дерев; нелегальні автомобільні перегони; неправильна дорожня розмітка; неправильна стоянка; незахищений прохід через автошляхи; незахищений залізничний переїзд; неправильна дорожня інфраструктура; нищення зелених насаджень; пересування в лісах із квадрациклами; перевищення дозволеної швидкості; розпивання алкоголю в несанкціонованих місцях; утоплення; споживання наркотичних засобів; випалення трави; дорожньо-транспортні пригоди, пов'язані з лісовими тваринами; погане поводження із тваринами; погана організація руху; жебрацтво. Після отримання інформації поліція має два дні, щоб зафіксувати іï, і п'ять днів для перевірки. У разі підтвердження інформація набуває статусу «підтверджено», а працівники відповідних підрозділів поліції здійснюють діяльність, спрямовану на усунення конкретної загрози. Деякі сигнали про загрози також передаються іншим службам (наприклад, муніципальним охоронцям або адміністраторам шляхів сполучення). Варто зазначити, що карта небезпеки не слугує для повідомлення про загрози, що потребують невідкладного втручання поліції. У таких випадках потрібно використовувати номери екстреної допомоги.

Обмін інформацією між громадськістю і поліцією вимагає подолання певного психологічного бар'єра як представниками громадськості, так і самими поліцейськими, чия поведінка часто $\epsilon$ наслідком попередньої системи. Сьогодні $\epsilon$ багато прикладів того, що обидві сторони зрозуміли, що партнерство $\epsilon$ найкращим способом побудови безпеки.

Відповідно до програми «Національна карта загрози безпеці» жителі громади можуть повідомляти інформацію анонімно на інтерактивному вебсайті про небезпеку в їхньому районі, що вимагає належної реакції відповідних служб. Такі заходи характерні для консультацій, які перелічені як одна з функцій, нерозривно пов'язаних із поліцейською діяльністю. Тому кожен підрозділ поліції повинен розробити політику контактів із мешканцями свого регіону, а також план роботи з ними та програму, яка інформує їх про проведену роботу. Працівники поліції превентивної діяльності не можуть бути анонімними для мешканців району, який вони обслуговують. Вони повинні бути знайомими і викликати довіру. Контакти працівників такої служби з мешканцями мають бути побудовані за допомогою заходів, які не пов'язані зі слідчою або оперативно-розшуковою роботою.

Схоже, що ідея Р. Піля, про те, що «поліція - це суспільство, а суспільство - це поліція», стає сьогодні у світі, у якому події повсякденного життя дедалі більше загрожують нашій безпеці, ефективним рецептом безпеки [4]. Варто зауважити, що зміст і форми безпеки не $\epsilon$ постійними, вона 
невіддільна від інших соціальних ситуацій, це явище живе і мінливе, маю власну динаміку.

Отже, зведення мостів, а не будівництво стіни, співпраця поліції із громадськістю у сфері охорони громадського порядку $\epsilon$ тією діяльністю, яка здатна гарантовано підвищити почуття безпеки. Це підтверджує досвід країн, які ухвалили рішення про таку модель роботи поліції. Організовані громадські обговорення й обмін інформацією через «Національну карту загрози безпеці» у Польщі $\epsilon$ діяльністю, яка формує суспільну обізнаність у сфері відповідальності за стан безпеки в місцевих громадах. Отже, це повинно привести до створення міцного партнерства в галузі громадської безпеки та громадського порядку, що дозволяє виявляти, ідентифікувати та ліквідувати криміногенні чинники, перш ніж вони загострюються. Така форма співробітництва між поліцією та громадянами у сфері захисту й охорони громадського порядку, на нашу думку, виправдана тим, що вона підвищує в місцевій громаді переконання про іï реальний вплив на безпеку в місці проживання.

\section{Література}

1. Про рішення Ради національної безпеки i оборони України від 4 березня 2016 р. «Про Концепцію розвитку сектора безпеки і оборони України» : Указ Президента України від 14 березня 2016 р. № $92 / 2016$.

2. Миронюк Р.В. Громадський контроль за діяльністю поліції : монографія. Дніпро : ДДУВС, 2020. $134 \mathrm{C}$.

3. Krajowa Mapa Zagrożeń Bezpieczeństwa. URL : http://www.policja.pl/pol/mapa-zagrozen-bezpiecze/ 33880, dok.html.

4. Чимаров С.Ю. К вопросу о «принципах правоприменения» Роберта Пиля в деятельности полиции. Вестник Санкт-Петербургского университета Министерства внутренних дел России. 2017. № 3 (75). С. 33-34.

Калаянов Д. П., доктор юридичних наук, професор, завідувач кафедри державно-правових дисциплін Одеського державного університету внутрішніх справ 